\title{
Correlation of Age With Hemoglobin Levels in Trained Soccer Athlete
}

\author{
Erpita Yanti ${ }^{*}$, Tika Gustina ${ }^{2}$, and Rara Putri Meliza ${ }^{3}$ \\ 1,2,3 Faculty of Sport Science, Universitas Negeri Padang, Padang, Indonesia \\ "Corresponding author. Email: yantierpita@fik.unp.ac.id
}

\begin{abstract}
The problem in this study is the still low hemoglobin level in Rajawali Fc soccer athlete caused by several. The index of body mass, genes, physical activity is one of the factors that influence hemoglobin. purpose of this study was to determine the relationship of age with hemoglobin.This research is a quantitative approach with correlational design. The sample in this study was a Rajawali Fc athlete, amounting to 16 people with various ages. Based on the results of data analysis, the value of $t$ count $=1.384<\mathrm{t}$ table $=1.764$, which means there is no relationship between age and hemoglobin.
\end{abstract}

\section{Keywords: Age, hemoglobin level, trained athlete}

\section{INTRODUCTION}

Sport is a part of human daily activities that is useful for forming a healthy body and spirit. Until now sport has made a positive and tangible contribution to improving public health. Besides that, sport also plays a role in increasing the ability of the nation to carry out sustainable development systems. One effort to create a complete Indonesian man is by coaching through sports.

Sports are not only for the sake of education, recreation, and physical fitness, but also as a venue for competition to compete in the achievement of an achievement both individually and in groups. This is also confirmed in the Law of the Republic of Indonesia No. 3 of 2005 concerning the National Sports System Chapter II Article 4 which reads: "National sports functions to develop physical, spiritual, and social abilities as well as to shape the character and personality of a dignified nation. Keolah-ragaan nasional bertujuan memelihara dan meningkatkan kesehatan dan kebugaran, prestasi, kualitas manusia, menanamkan nilai moral dan akhlak mulia, sportsmanship, discipline, strengthen and foster national unity and integrity, strengthen national defense, and elevate the nation's dignity, dignity and honor ".

From the above quotation, it can be seen that various goals and objectives of Indonesian sports activities, one of which is in the form of fostering sports achievements. This means that sports activities are not only for physical fitness but also to improve sports achievements in order to make the name of the nation and state proud. As an achievement sport covers almost all sports including: football, basketball, volleyball, swimming, badminton, tennis, takraw and others.
In every championship both in the area and in the national arena all athletes competing to find achievements in their respective fields to be able to raise the name of the contingent or region. Among the many sports that are currently being developed, one that gets attention and guidance is soccer Football is a dynamic sport that requires excellent physical condition.

In playing physical football is one of the basic components that a player must have because with the technique of dribble, chasing. Seizing, the ball from the opponents is a physical factor. And also many of the movements involved in playing soccer are like jumping, footwork and a quick headgear to all directions.

A good soccer athlete must have good basic soccer skills, and be trained with the correct training methods so that the resulting movements are also correct. In individuals who regularly exercise their hemoglobin levels are low. Because $\mathrm{O}_{2}$ will be much more needed by the tissues while engaging in activities. (Bahri et al., 2009) in Mirza Juanda (2014) [1]. In doing soccer movements can increase physical activity, meaning that exercise requires a lot of oxygen, where in the body oxygen-producing role as a transport medium that delivers oxygen throughout the body is hemoglobin.

Hemoglobin is a protein compound with $\mathrm{Fe}$ called conjugated protein. As the point $\mathrm{Fe}$ and with protoperphyrin and globin (tetra phirin) cause red blood color because of this $\mathrm{Fe}$. Eryt $\mathrm{Hb}$ binds to carbon dioxide into carboxy hemoglobin and has a deep red color. Arterial blood contains oxygen and venous blood containing carbon dioxide (MOH RI in Widayanti, 2008) [2]. 
Hemoglobin has two important transportation functions in the human body, namely the transport of oxygen from the respiratory organs to the oxygen is breathing to the periphel and carbondioxed tissues of cells with multiple protons from the tissues of cells to the respiratory organ to be exhaled.

Hemoglobin accounts for abous 15 grams per ounce $[15 \mathrm{ml}]$ in blood, and "100 percents" in hemoglobin (Evelyn,2009) [3]. In each group for a difference in the number of hemoglobin but the who has determined normal hemoglobin level to average sex sex (WHO in Arisman, 2002) [4].

Table 1. Hemoglobin Level Limits

\begin{tabular}{|c|l|}
\hline \multicolumn{1}{|c|}{$\begin{array}{c}\text { Age Group } \\
\text { Hemoglobin }\end{array}$} & Value Limit (Gr / DI) \\
\hline $\begin{array}{l}\text { Children 6 months -6 } \\
\text { years }\end{array}$ & 11.0 \\
\hline $\begin{array}{l}\text { Children 6 years -14 } \\
\text { years }\end{array}$ & 12.0 \\
\hline Adult men & 13.0 \\
\hline Pregnant women & 11.0 \\
\hline Adult women & 12.0 \\
\hline
\end{tabular}

Source: WHO in Arisman 2002[4]

Table 2. Normal Limits of Hemoglobin Levels for Each Age Group

\begin{tabular}{|l|c|l|}
\hline Hemoglobin & Age Group & (gr / 100ml) \\
\hline Children & $\begin{array}{c}\text { 1. Children 6 } \\
\text { months -6 } \\
\text { years } \\
\text { 2. 6-14 years }\end{array}$ & $\mathbf{1 1}$ \\
\hline Adult & $\begin{array}{c}\text { 1. Male } \\
\text { 2. Women } \\
\text { 3. Pregnant } \\
\text { women }\end{array}$ & $\mathbf{1 3}$ \\
\hline
\end{tabular}

\section{Source: MOH RI, 1999 (Zarianis, 2006) [5]}

Hemoglobin levels will increase slightly when a person is exercising properly, measured and regularly. Because sast undergoes a massive network of radio staus need $\mathrm{O} 2$ (oxygen). A good soccer athlete must do physical training in order to have good basic soccer skills, and be trained with the correct training methods so that the resulting movements are also correct. routine and programmed exercise because in other words regular and regular exercise will bring changes to the body's physiological system.

Changes that occur include the pulse in exercise will increase, blood pressure at rest will be normal, hemoglobin levels will increase because this hemoglobin will carry oxygen from the lungs to all body tissues including skeletal muscle cells and the ability of the lungs to supply oxygen to cells. body cells increase, because soccer is a sport that requires a large supply of oxygen to become a source of energy and the formation of Adenosine Tri Phosphate (ATP) as energy as well (Ferry, 2019) [6].

Some of the factors that influence hemoglobin levels are: age, food, sex, physical activity, lifestyle, genetics, and nutritional status. The importance of the function of hemoglobin in the human body and the importance of someone doing regular physical activity are two interrelated things.

The relationship between physical activity a person does on hemoglobin levels in a study that when a person performs Sports such as physical activity, which can increase the metabolic activity produced (lactic acid hydrogen ions) so that it can increase the amount so that it becomes a decrease in $\mathrm{PH}$. Low $\mathrm{pH}$ will reduce the between hemoglobin and oxygen.

Which causes oxygen hemoglobin to release a lot so that oxygen has increased to the muscles.

Based on the above discussion, this study aims to determine the relationship between age and hemoglobin.

\section{METHODS}

This study uses a quantitative approach with a correlational design, to see the relationship of age with hemoglobin. The sample in this study were athletes Rajawali Fc, totaling 16 people with ages $14-20$ years.

The instrument in this study was in the form of TKJI test. For the Hemoglobin variable The test determining the hemoglobin level is Indonesian Physical Fitness (TKJI) for ages 14-20 years.

\section{RESULT AND DISCUSSION}

In theory, the conceptual framework of this research is.

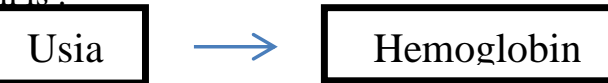

Variables Entered/Removed ${ }^{\mathrm{b}}$

\begin{tabular}{|c|c|c|c|}
\hline $\begin{array}{c}\text { Mod } \\
\text { el }\end{array}$ & $\begin{array}{c}\text { Variables } \\
\text { Entered }\end{array}$ & $\begin{array}{c}\text { Variables } \\
\text { Removed }\end{array}$ & Method \\
\hline 1 & Usia $^{\mathrm{a}}$ & & Enter \\
\hline
\end{tabular}


a. All requested variables entered.

b. Dependent Variable: HB

Model Summary

\begin{tabular}{|c|c|r|r|r|}
\hline $\begin{array}{c}\text { Mod } \\
\text { el }\end{array}$ & $\mathrm{R}$ & $\begin{array}{c}\mathrm{R} \\
\text { Square }\end{array}$ & $\begin{array}{c}\text { Adjusted R } \\
\text { Square }\end{array}$ & $\begin{array}{c}\text { Std. Error } \\
\text { of the } \\
\text { Estimate }\end{array}$ \\
\hline 1 & $.347^{\mathrm{a}}$ & .120 & .058 & 1.174 \\
\hline
\end{tabular}

a. Predictors: (Constant), Usia

ANOVA $^{\mathrm{b}}$

\begin{tabular}{|c|c|c|c|c|c|}
\hline Model & $\begin{array}{l}\text { Sum of } \\
\text { Squares }\end{array}$ & Df & $\begin{array}{l}\text { Mean } \\
\text { Square }\end{array}$ & $\mathrm{F}$ & Sig. \\
\hline $\begin{array}{c}\text { Regressi } \\
\text { on }\end{array}$ & 2.640 & 1 & 2.640 & 1.915 & $.188^{a}$ \\
\hline $\begin{array}{c}\text { Residua } \\
1\end{array}$ & 19.297 & 14 & 1.378 & & \\
\hline Total & 21.937 & 15 & & & \\
\hline
\end{tabular}

a. Predictors: (Constant), Usia

b. Dependent Variable: HB

Coefficients $^{\mathrm{a}}$

\begin{tabular}{|c|c|c|c|c|c|}
\hline \multirow[b]{2}{*}{ Model } & \multicolumn{2}{|c|}{$\begin{array}{l}\text { Unstandardized } \\
\text { Coefficients }\end{array}$} & \multirow{2}{*}{$\begin{array}{c}\begin{array}{c}\text { Standard } \\
\text { ized } \\
\text { Coeffici } \\
\text { ents }\end{array} \\
\text { Beta } \\
\end{array}$} & \multirow[b]{2}{*}{$\mathrm{t}$} & \multirow[b]{2}{*}{ Sig. } \\
\hline & B & $\begin{array}{l}\text { Std. } \\
\text { Error }\end{array}$ & & & \\
\hline $\begin{array}{cc}1 & \text { (Const } \\
\text { ant })\end{array}$ & 11.319 & 2.362 & & \begin{tabular}{|l|}
4.792 \\
\end{tabular} & .000 \\
\hline Usia & .151 & .109 & .347 & $\mid 1.384$ & .188 \\
\hline
\end{tabular}

a. Dependent Variable: HB

Based on the results of the research from the above output we can find the value of $\mathrm{r}$ count $=1.384$ with a significance value of $0.188>0.05$, which means there is no significant influence (significance) of the variable $\mathrm{X}$ (age) with the variable $\mathrm{Y}(\mathrm{HB})$.

\section{CONCLUSION}

Research that has been done by researchers some time ago has answered the hypothesis that researchers proposed before. Based on these results it was found that: $r$ count $=1,384$ with a significance value of $0.188>$
0.05 , which means there is no significant effect (significance) variable $\mathrm{X}$ (age) with variable $\mathrm{Y}(\mathrm{HB})$.

There is no relationship between age and hemoglobin levels in trained soccer athletes.

\section{REFERENCES}

[1] Mirza, Kosasi Laura, et al. (2014). Hubungan antara Aktivitas Fisik dan Tingkat Hemoglobin pada Anggota Mahasiswa Universitas Andalas Pandekar UKM. (health journal), 2014, 178-181

[2] Widayanti, Ismaryati. (2008). Tes dan Pengukuran Olahraga.Surakarta: UNS Press

[3] Evelyn 2009. Anatomy and physiology for parameters, printing to 23 gramedia major libraries. Jakarta.

[4] Arisman, Batty, Eric. 2002. Pelatihan Metode Sepak Bola Baru. Bandung: Pioner Jaya.

[5] Zarianis,Riduwan and Engkos Achmad Kuncoro (2006). Cara Menggunakan dan Menggunakan Analisis Jalur.Bandung: Alfabeta.

[6] Ferry, M. William, Wilda Welis. (2019) Hubungan Kadar Hemoglobin Terhadap Kemampuan Vo2max Pada Pemain Sekolah Sepakbola (Ssb) Tunas Inti Kecamatan Sungai Bungkal Kota Sungai Penuh. (Journal of Stamina), 2019, Volume 2, Number 1, 425-436

[7] Bafirman. (2008). Buku Ajar Kondisi Fisik.. Padang: Faculty of Sport Science, Padang State University. Wineka Media.

[8] Syafrizal And Wilda Wellis. 2009. Gizi Olahraga. Malang: Wineka Media. 